\title{
IUGR Alters Postnatal Rat Skeletal Muscle Peroxisome Proliferator-Activated Receptor- $\gamma$ Coactivator-1 Gene Expression in a Fiber Specific Manner
}

\author{
ROBERT H. LANE, NICOLE K. MACLENNAN, MONICA J. DAOOD, JENNIFER L. HSU, \\ SARA M. JANKE, THO D. PHAM, AARTI R. PURI, AND JON F. WATCHKO \\ David Geffen School of Medicine@UCLA, Mattel Children's Hospital@UCLA, Department of \\ Pediatrics, Division of Neonatology and Developmental Biology, Los Angeles CA 90095-1752, U.S.A. \\ [R.H.L., N.K.M., J.L.H., S.M.J., T.D.P., A.R.P.]; University of Pittsburgh School of Medicine, Department \\ of Pediatrics, Division of Neonatology and Developmental Biology, Magee-Womens Research Institute, \\ Pittsburgh PA 15213, U.S.A. [M.J.D., J.F.W.]
}

\begin{abstract}
Uteroplacental insufficiency and subsequent intrauterine growth retardation (IUGR) increase the risk of insulin resistance in humans and rats. Aberrant skeletal muscle lipid metabolism contributes to the pathogenesis of insulin resistance. Peroxisome proliferator-activated receptor- $\gamma$ co-activator-1 (PGC-1) is a transcriptional co-activator that affects gene expression of key lipid metabolizing enzymes such as carnitine palmitoyltransferase I (mCPTI). Because gene expression of lipid metabolizing enzymes is altered in IUGR postnatal skeletal muscle, and we hypothesized that PGC-1 expression would be similarly affected. To prove this hypothesis, bilateral uterine artery ligation and sham surgery were used to produce IUGR and control rats respectively. Western Blotting demonstrated that PGC-1 hind limb skeletal muscle protein levels were increased in perinatal and postnatal IUGR rats. Conventional RT-PCR demonstrated that PGC-1 mRNA levels were similarly increased in perinatal hind limb skeletal muscle and juvenile extensor digitorum longus (EDL), but were decreased in juvenile soleus. Because a gender specific trend was noted in PGC-1 mRNA levels, real time RT-PCR was used for further differentiation. Real time RT-PCR
\end{abstract}

ABSTRACT

revealed that changes in postnatal skeletal muscle PGC-1 expression were more marked in male IUGR rats versus female IUGR rats. Down stream targets of PGC-1 followed a similar pattern of expression. We conclude that PGC-1 expression is altered in rat IUGR skeletal muscle and speculate that it contributes to the pathogenesis of insulin resistance in the IUGR rat. (Pediatr Res 53: 994-1000, 2003)
CD36, fatty acid translocase
Abbreviations
CoxIV, cytomchrome $c$ oxidase subunit I
EDL, extensor digitorum longus
IUGR, intrauterine growth retardation
mCPTI, muscle isoform of carnitine palmitoyl-transferase I
mTFA, mitochondrial transcription factor A
NRF-1, nuclear respiratory factor 1
PGC-1, peroxisome proliferator-activated receptor- $\gamma$
coactivator-1
UCP-2, uncoupling protein 2

Barker's Fetal Origins of Adult Disease Hypothesis proposes that fetal adaptation to a deprived intrauterine milieu leads to permanent changes in cellular biology and systemic physiology (1). Intrauterine growth retardation (IUGR) predisposes affected newborns toward the development of insulin resistance and dyslipidemia (2). Although both insulin defi-

Received August 6, 2002; accepted January 20, 2003.

Correspondence: Robert H. Lane, David Geffen School of Medicine @ UCLA, Mattel Children's Hospital @ UCLA, B2-375 MDCC, 10833 Le Conte Ave., Los Angles CA 90095-1752, U.S.A.; e-mail: rlane@ mednet.ucla.edu

National Institute of Child Health and Human Development Grant K08-BD-01225-1, R01 HD41075 and an American Diabetes Association Grant supported this work.

DOI: 10.1203/01.PDR.0000064583.40495.51 ciency and resistance contribute to the IUGR diabetic phenotype, asymmetrical IUGR individuals are often characterized by insulin resistance. Uteroplacental insufficiency, a morbidity associated with many common complications of pregnancy induces asymmetrical IUGR $(3,4)$. In the rat, uteroplacental insufficiency results in juvenile IUGR animals whose glucose homeostasis is abnormal only when physiologically challenged on a pharmacological level (5). By adulthood, these IUGR rats develop overt diabetes that is characterized by insulin resistance and hypertriglyceridemia $(5,19,20)$.

An important component contributing to the pathogenesis of skeletal muscle insulin resistance is altered fatty acid homeostasis $(6,7)$. Hind limb skeletal muscle from 21-d-old 
IUGR rats is characterized by increased skeletal muscle triglycerides and increased mRNA levels of carnitine palmitoyl transferase I (mCPTI), which is an important rate limiting enzyme of fatty acid oxidation $\beta$-oxidation $(8,9)$. Peroxisome proliferator-activated receptor- $\gamma$ coactivator- 1 (PGC-1) is a transcriptional co-activator that induces expression of mCPTI, as well as other mitochondrial proteins such uncoupling protein-2 (UCP-2) $(10,11)$. PGC-1 polymorphisms have been linked to an increased genotype relative risk of Type II diabetes, and PGC-1 expression is increased in IUGR rat liver $(12-14)$. We therefore hypothesized that PGC-1 gene expression would be similarly increased in postnatal rat skeletal IUGR skeletal muscle, and that the change in PGC-1 gene expression would be associated with increased expression of mCPT1 and UCP-2.

To prove this hypothesis, bilateral uterine artery ligation (IUGR) and sham surgery (CON) were performed on day 19 of gestation (term $21.5 \mathrm{~d}$ ). In this well characterized and widely published model of asymmetrical growth retardation, IUGR pups are $20 \%$ to $25 \%$ lighter than the sham operated control animals, and birth weights are normally distributed within and among litters $(3,5,8,9,12,15-19)$. Litter size does not significantly differ between control and IUGR groups (8). Skeletal muscle protein and mRNA levels of PGC-1 were measured in rats at day $0(\mathrm{~N} 0)$ and day 21 (J21) of postnatal life. The J21 rat were studied because they do not exhibit fasting hyperglycemia, hypertriglyceridemia, or hyperinsulinemia, and their peripheral insulin resistance is evident only when challenged with pharmacological levels of glucose (5, 20).

Conventional RT-PCR was used to determine PGC-1 mRNA levels in soleus (type I) and extensor digitorum longus (EDL) (type II) fibers in J21 animals, and a trend was noted differentiating expression between male and female animals IUGR animals. As a result, real time RT-PCR was used to further differentiate gender specific PGC-1 mRNA expression, as well as two of its down stream targets, carnitine palmitoyl transferase I (mCPTI) and uncoupling protein 2 (UCP2). CD36 mRNA levels were measured to determine whether they are potentially related to PGC-1 expression. CD36 is a fatty acid translocase whose mRNA levels have been directly linked to increased skeletal muscle triglycerides, a characteristic of the juvenile IUGR rat $(9,21)$.

\section{METHODS}

Animals. All procedures were approved by the UCLA Chancellor's Animal Research Committee. These surgical methods have been previous described $(8,9,20,22)$. On day 19 of gestation, the maternal rats were anesthetized with intraperitoneal xylazine $(8 \mathrm{mg} / \mathrm{kg})$ and ketamine $(40 \mathrm{mg} / \mathrm{kg})$, and both uterine arteries were ligated (IUGR) $(n=8$ litters). Sham surgery was performed upon control animals who underwent identical anesthetic and surgical procedures except for the uterine artery ligation $(\mathrm{CON})(\mathrm{n}=8$ litters). N0 pups were delivered by caesarian section ( $n=4$ litters CON and IUGR respectively).
For conventional and real time RT-PCR N0 studies, hind limb RNA was isolated and quantified from 3 individual animals. Because N0 animals do not provide a great deal of hind limb skeletal muscle, samples from three animals per litter were pooled for protein isolation. The remaining maternal rats were allowed to deliver spontaneously, and litters were randomly culled to 6 to minimize any effects due to litter size (23).

J21 animals were separated from their dams for $4 \mathrm{~h}$ (to minimize individual hormonal variations associated with feeding), anesthetized, and killed ( $\mathrm{n}=4$ litters Con and IUGR respectively). Whole hind limb skeletal muscle was harvested at J21 for Western Blotting from 3 animals per litter. Similarly, extensor digitorum longus (EDL) and soleus were harvested at J21 for both conventional and real time RT-PCR from three animals per litter.

Western blotting. Protein was isolated by centrifugation after tissue homogenization in Laemmeli lysis buffer. $100 \mu \mathrm{g}$ of protein was separated on a SDS-PAGE gel along with molecular weight markers and subsequently transferred to nitrocellulose. The nitrocellulose was incubated in Blotto solution, and then with rabbit PGC-1 primary antibody (1:100) (Chemicon, Temecula CA). The filters were then washed before incubation with secondary anti-rabbit antibody $(1: 1000$ dilution). The filters were washed, and detection was performed using ECL chemiluminiescence (Amersham, Piscataway NJ). The products were quantified by densitometry after standardization for loading. Each blot was replicated three times.

Muscle fiber typing. To determine whether differences in J21 PGC-1 protein levels may be due to differences muscle fiber type distribution, myosin heavy chain isoforms were quantified. Hind limb muscles from 21-d-old rats were removed and scissor minced in four volumes of Guba-Straub high salt buffer, $\mathrm{pH}$ 6.5. Extracts were centrifuged at 13,000 $\times$ $g$ and the supernatants were recovered for electrophoresis (24). Extracted myosin was diluted 10 -fold in $1 \mathrm{mM}$ EDTA and $0.1 \% 2$-mercaptoethanol, stored overnight at $4^{\circ} \mathrm{C}$ to precipitate myosin filaments, and centrifuged to pellet filaments. These were subsequently dissolved in $0.5 \mathrm{M} \mathrm{NaCl}$ and $10 \mathrm{mM}$ $\mathrm{NaH}_{2} \mathrm{PO}_{4}$ and diluted in sample buffer. Electrophoresis was carried out according to the protocol described previously (25). Briefly, mini-gels consisting of $8 \%$ acrylamide separating gels and $4 \%$ stacking gels were run at $70 \mathrm{~V}$ for $24 \mathrm{~h}$ at $4{ }^{\circ} \mathrm{C}$. Both separating and stacking gels contained $30 \%$ glycerol. Approximately $1 \mu \mathrm{g}$ of myosin extract wad loaded per sample. Gels were silver stained and quantitated with a scanning densitometer. Each sample was scanned 5 times.

$\boldsymbol{R N A}$ isolation. Total RNA was extracted from skeletal muscle and quantified in triplicate using UV absorbance (26). Gel electrophoresis confirmed the integrity of the samples. RNA was treated to DNase (Ambion Inc, Austin TX).

RT-PCR Quantification Using Internal Control and Direct Incorporation of Radioactivity. To measure mRNA levels of PGC-1, a well-characterized method of RT-PCR was used that incorporates bovine retinal rhodopsin RNA as an internal control for both reverse transcription and amplification $(8,9$, $20,22)$. cDNA was synthesized using random hexamers and SUPERSCRIPT II RTTM (Life Technologies Inc., Gaithers- 
burgh MD) from $1.0 \mu \mathrm{g}$ of skeletal muscle RNA added to 0.01 $\mu \mathrm{g}$ of bovine retinal RNA. Reactions were replicated three times. Primer sequences are found in Table 1. With each set of reverse transcription and amplification, serial dilutions were run to demonstrate that both PCR products were being produced in the exponential phase of amplification. Products were separated and radioactivity was quantified by phosphorimaging. The relative abundance of target mRNA levels were quantified relative to that of the control rhodopsin band from the same reaction.

Verification of PGC-1 Expression in the IUGR Rat. Previous investigators have found that PGC-1 controls expression of genes affecting mitochondrial biogenesis and respiration (10). Because the perinatal IUGR rat is characterized by increased skeletal muscle mRNA levels of the mitochondrial gene NADH ubiquinone-oxireductase 4L, we cross-referenced our findings by measuring mRNA levels of nuclear mitochondrial transcription factor A (mTFA), nuclear respiratory factor-1 (NRF-1), and cytochrome oxidase subunit IV (Cox IV) in N0 IUGR rats using the technique described above (8).

Real Time RT-PCR. Skeletal muscle mRNA levels of PGC-1, mCPT1, UCP-2, and CD36 were measured at J21 (12) as previously described. cDNA was synthesized from $0.5 \mu \mathrm{g}$ of DNase treated mRNA as described above. Target (PGC-1, mCPTI, UCP-2, CD36) primers and probes were designed using Primer Express Software ${ }^{\mathrm{TM}}$ (Applied Biosystems, Foster CA) (Table 1); target probes were labeled with fluorescent reporter dye FAM. Before the performance of real time PCR, all primer pairs are tested with serial $\mathrm{Mg}^{+2}$ and primer concentrations to determine the optimal reaction conditions and to demonstrate the specificity of each primer pair. Reporter dye emission is detected by an automated sequence detector combined with ABI Prism 7700 Sequence Detection System ${ }^{\mathbb{B}}$ software (Applied Biosystem, Foster CA). An algorithm normalizes the reporter signal $\left(R_{n}\right)$ to a passive reference and multiples the $\mathrm{SD}$ of the background $\mathrm{R}_{\mathrm{n}}$ in the first cycles by a default factor of 10 to determine threshold $\mathrm{C}_{\mathrm{T}}$. $\mathrm{C}_{\mathrm{T}}$ has a linear relation with the logarithm of the initial template copy number (27). Real time PCR quantification is then performed using the Taqman ${ }^{\circledR}$ glyceraldehyde-3-phosphate dehydrogenase controls. Before the use of GAPDH as a control, serial dilutions of cDNA are quantified to prove the validity of using GAPDH as an internal control. Relative quantification of PCR products are then based upon value differences between the target and
Table 2. Hind limb skeletal muscle fiber typing in 21 control and IUGR

\begin{tabular}{lcccc}
\hline & Type 2A & Type 2X & Type 2B & I (slow) \\
\hline IUGR & $18.5 \pm 2.1$ & $28.7 \pm 0.8$ & $36.7 \pm 3.4$ & $16.2 \pm 1.8$ \\
Control & $17.4 \pm 0.1$ & $27.3 \pm 0.3$ & $39.6 \pm 2.7$ & $15.7 \pm 1.5$ \\
\hline
\end{tabular}

Results are expressed as mean percentage \pm SEM.

GAPDH control using the comparative $\mathrm{C}_{\mathrm{T}}$ method (28). Cycle parameters were $55^{\circ} \mathrm{C} \times 5 \mathrm{~min}, 95^{\circ} \mathrm{C} \times 10 \mathrm{~min}$, and then 40 cycles of $95^{\circ} \mathrm{C} \times 15 \mathrm{~s} \rightarrow 58^{\circ} \mathrm{C} \times 60 \mathrm{~s}$. Each sample was analyzed in triplicate in assays performed on three occasions.

Statistics. All data presented are expressed as mean percent of control \pm SEM. For RT-PCR using the internal control, statistical analyses were performed using the nonparametric Wilcoxon Matched Pair Test. For muscle fiber typing, Western Blotting, and real time RT-PCR, statistical analyses were performed using ANOVA (Fisher's protected least significance difference) and Student's unpaired $t$ test.

\section{RESULTS}

Skeletal muscle PGC-1 protein levels at NO and J21. Uteroplacental insufficiency and subsequent IUGR increased N0 hind limb PGC-1 protein levels to $220 \pm 19 \%$ * of sham operated control values (Fig. $1 A)(* p<0.05)$. Similarly, J21 hind limb PGC-1 protein levels were increased in IUGR skeletal muscle to $165 \pm 17 \%^{*}$ of sham operated control values (Fig. $1 A)(* p<0.05)$.

Skeletal muscle PGC-1 mRNA levels using traditional $\boldsymbol{R T}$-PCR. Using a traditional method of RT-PCR in which radioactivity is directly incorporated into the PCR product, we found that uteroplacental insufficiency increased PGC-1 mRNA levels in N0 hind limb skeletal muscle to $169 \pm 12 \%$ * of control values (Fig. $1 B)(* p<0.05)$. Consistent with the established link between PGC-1 gene expression and mTFA, NRF-1, and CoxIV mRNA levels, as well as the previous report of increased mitochondrial gene expression in N0 skeletal muscle, day 0 mRNA levels of mTFA $\left(177 \pm 12 \%^{*}\right)$, NRF-1 $(201 \pm 9 \% *)$, and CoxIV $\left(189 \pm 12 \%^{*}\right)$ were also significantly increased in N0 IUGR hind limb muscle $\left({ }^{*} p<\right.$ $0.05)$.

At day 21 of life, IUGR similarly increased PGC-1 mRNA levels in EDL skeletal muscle to $142 \pm 11 \% *$ of control

Table 1. Sequences of PCR primers

\begin{tabular}{|c|c|c|c|c|}
\hline Gene & Sense primer & Antisense primer & Probe sequence & $\begin{array}{c}\text { GenBank } \\
\text { Accession No. }\end{array}$ \\
\hline PGC-1 & CGCACAACTCAGCAAGTCCTC & CCTTGCTGGCCTCCAAAGTCTC & NA & AB025784 \\
\hline PGC-1 & TCTGGAACTGCAGGCCTAACTC & GCAAGAGGGCTTCAGCTTTG & TCCTCCTCATAAAGCCAACCAAGATAACCT & \\
\hline \multirow[t]{2}{*}{ CD36 } & GGAAAGTTATTGCGACATGATTAATG & GGAAAGAACCTCAGTGTTTGAGACTTC & & AF072411 \\
\hline & & & ATGCAGCCTCCTTTCCACCTTTTGTTGA & \\
\hline CoxIV & TGTTGATCGGCGTGACTACC & GAAGCCGATGAAGAACATGG & NA & \\
\hline mTFA & CCCTGGAAGCTTTCAGATACG & AATTGCAGCCATGTGGAGG & NA & AF246196 \\
\hline mCPT1 & ACCTGGGCTACACGGAGACA & CCTTGGCTACTTGGTACGAATTCT & AACAACAAGTTGCCGCCGCCT & NM013200 \\
\hline NRF-1 & TTACAGGGCGGTGAAATGAC & GTTAAGGGCCATGGTGACAG & NA & RNU27700 \\
\hline $\mathrm{UCP}-2$ & CTGAAAGCCAACCTCATGACAG & CAATGACGGTGGTGCAGAAG & CGACCTCCCTTGCCACTTCACTTCTG & NM019354 \\
\hline Rhodospin & TATTCTTCTGCTACGGGCAG & ATGGGTGAAGATGTAGAACG & NA & M21606 \\
\hline
\end{tabular}

NA, not available. 


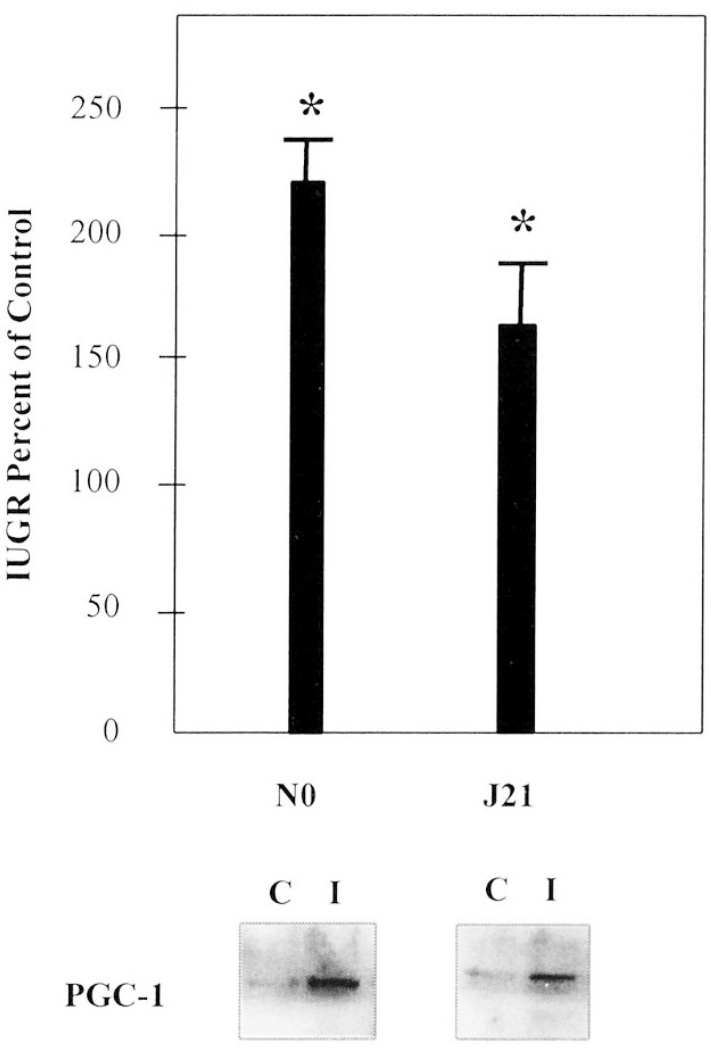

PGC-1 Protein

$1 \mathrm{~A}$
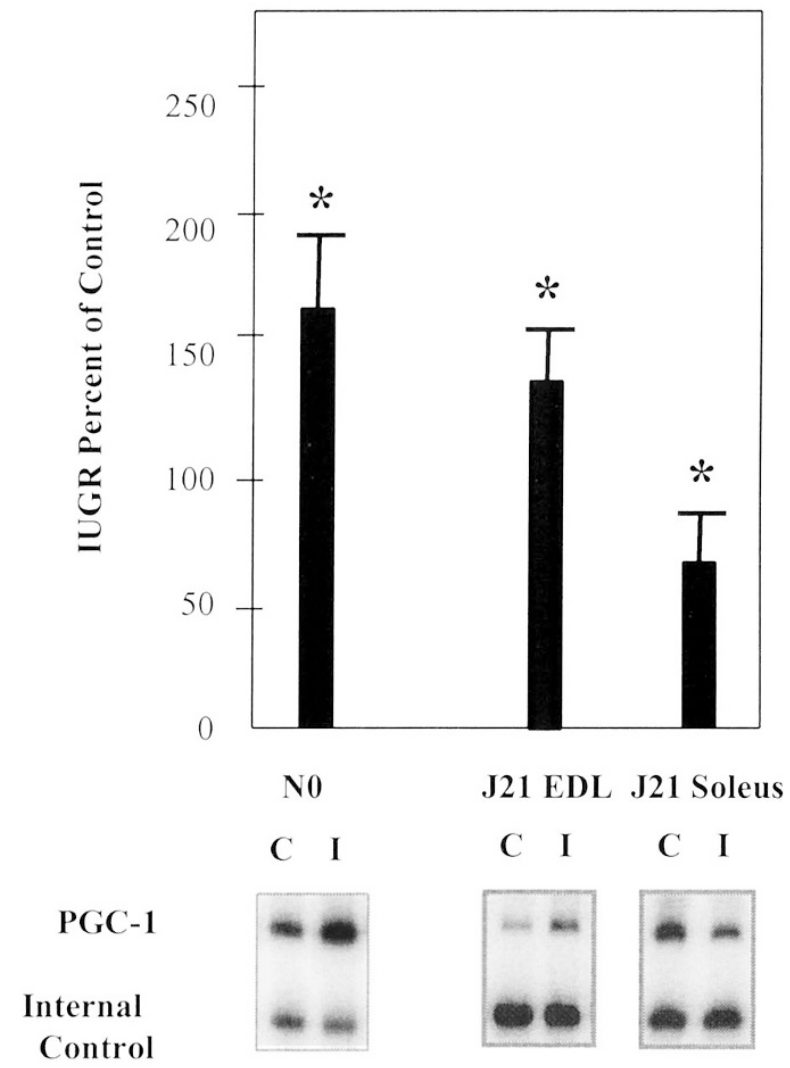

PGC-1 mRNA

$1 \mathrm{~B}$

Figure 1. (A) Quantification of sham operated control (C) and IUGR (I) PGC-1 protein levels in N0 and J21 hindlimb muscle with a representative Western blot. Protein levels are expressed as mean IUGR percent of control \pm SD. Protein was quantified using NIH image software. (B) Quantification of sham operated control and IUGR PGC-1 mRNA levels from N0 hindlimb, J21 EDL, and J21 soleus with representative phosphorimages. mRNA levels are expressed IUGR mean percent of contrlo \pm SEM. PCR products were quantified using phosphorimage analysis. ${ }^{*} p<0.05$.

values; in contrast, PGC-1 mRNA levels were decreased to 67 $\pm 10 \% *$ of control values in IUGR soleus (Fig. $1 B)\left({ }^{*} p<\right.$ $0.05)$.

Skeletal muscle fiber typing. To determine whether uteroplacental insufficiency induced IUGR affected skeletal muscle fiber distribution and thereby contributed to the increased $\mathbf{J} 21$ PGC-1 hind limb protein levels observed above, whole hind limb skeletal muscle fiber types were determined by proportioning myosin heavy chain isoforms. In J21 control animals, hind limb skeletal muscle was comprised of $17.4 \pm 0.1 \%$ Type $2 \mathrm{~A}, 27.3 \pm 0.3 \%$ Type $2 \mathrm{X}, 39.6 \pm 2.7 \%$ Type $2 \mathrm{~B}$, and $15.7 \pm$ $1.5 \%$ Type I fibers. In the J21 IUGR animals, hind limb skeletal muscle was comprised of $18.5 \pm 2.1 \%$ Type $2 \mathrm{~A}, 28.7$ $\pm 0.8 \%$ Type $2 \mathrm{X}, 36.7 \pm 3.4 \%$ Type $2 \mathrm{~B}$, and $16.2 \pm 1.8 \%$ Type 1 fibers. No significant difference exists between control and IUGR animals.

Real time RT-PCR. Gender specific analysis of PGC-1 mRNA levels led to the conclusion that the extent IUGR affected PGC-1 mRNA levels differed between the sexes at J21. Real Time RT-PCR was subsequently used to determine PGC-1 mRNA levels in J21 EDL and soleus of both genders because of the technique's preciseness.

Uteroplacental insufficiency increased PGC-1 mRNA levels to $200 \pm 7 \%^{* *}$ of control values in J21 male EDL; in contrast, female PGC-1 EDL mRNA levels were increased to only 123 $\pm 5 \% *$ of control values (Fig. 2$)(* * p<0.01)(* p<0.05)$. In soleus, male IUGR PGC-1 mRNA levels were decreased to $53 \% \pm 2 \% *$, versus $81 \pm 4 \%^{*}$ in IUGR female soleus versus control values (Fig. 2) $\left({ }^{*} p<0.05\right)$.

mRNA values of the proven PGC-1 down stream targets followed a similar pattern. Uteroplacental insufficiency and subsequent IUGR increased male EDL $\mathrm{mCPT} 1$ and UCP-2 mRNA levels to $214 \pm 8 \%^{* *}$ and $282 \pm 11 \% * *$ of control values respectively, whereas female EDL mCPTI and UCP-2 mRNA levels were increased to only $115 \pm 6 \%$ and $132 \pm$ $6 \% *$ of control values (Fig. 2$)\left({ }^{* *} p<0.01\right)(* p<0.05)$. In soleus, male IUGR mCPTI and UCP-2 mRNA levels decreased to $37 \pm 2 \% * *$ and $53 \pm 5 \% *$ of control values respectively versus a change of $61 \pm 5 \% *$ and $62 \pm 4 \% *$ in J21 female soleus (Fig. 2) $\left({ }^{* *} p<0.01\right)\left({ }^{*} p<0.05\right)$.

Interestingly, CD36 mRNA levels did not follow this pattern. In J21 EDL, uteroplacental insufficiency and subsequent IUGR increased CD36 mRNA levels to $141 \pm 5 \%$ ** and 246 $\pm 13^{* *}$ in male and female animals respectively (Fig. 2) $(* * p$ $<0.01)$. Similarly, soleus CD36 mRNA levels were increased to $114 \pm 6 \%$ and $174 \pm 7 \% *$ in IUGR male and female animals respectively (Fig. 2$)\left({ }^{*} p<0.05\right)$. 


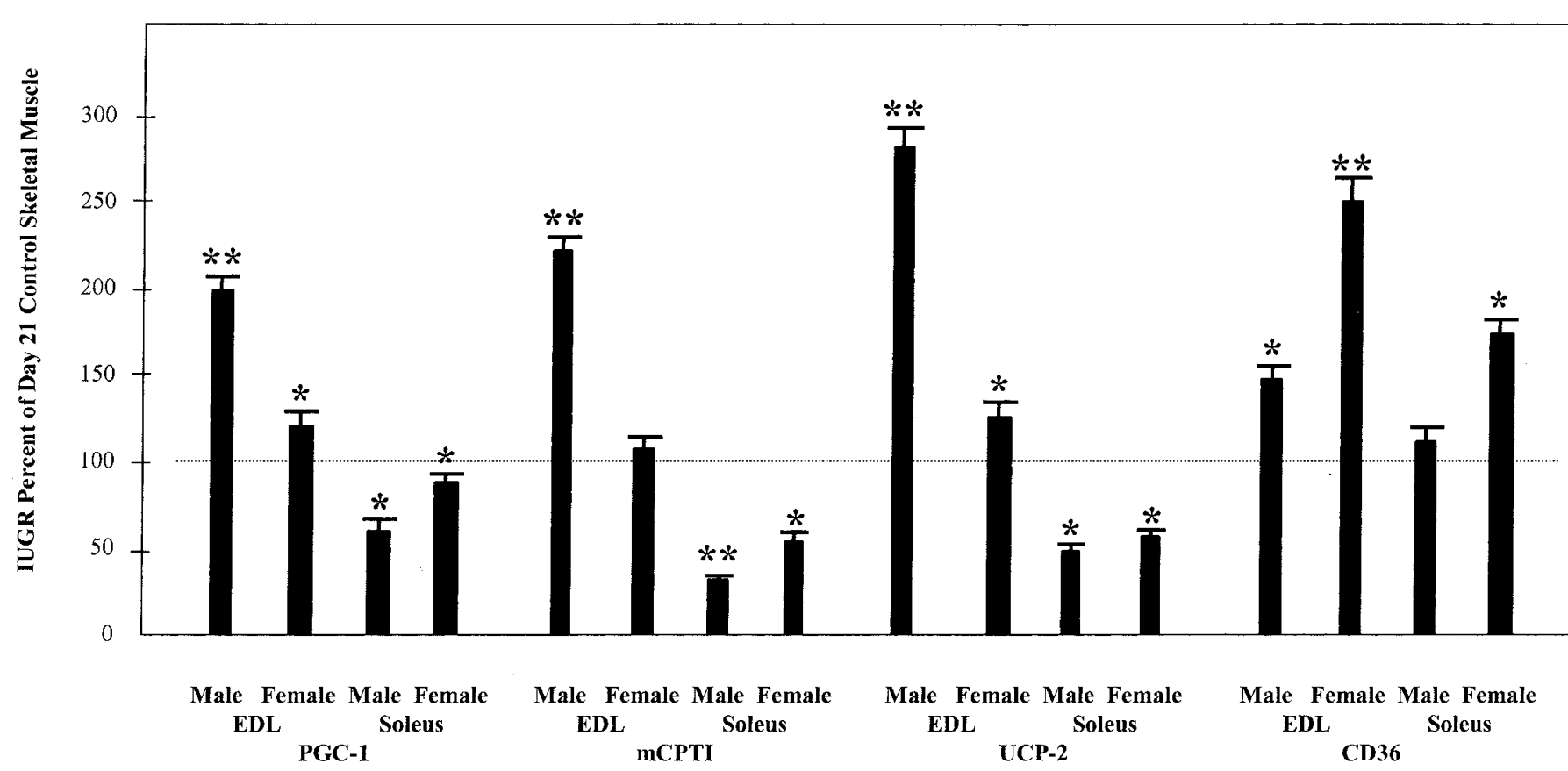

Figure 2. Quantification of PGC-1, mCPTI, UCP2, and CD36 using real time RT-PCR in J21 EDL and soleus. Results are expressed as mean percentages \pm SEM relative to sham-operated controls. Relative quantification of PCR products are based on value differences between the target and GAPDH control, using the comparative $\mathrm{C}_{\mathrm{T}}$ method. ${ }^{* *} p<0.01,{ }^{*} p<0.05$.

\section{DISCUSSION}

Uteroplacental insufficiency in the human and the rat causes fetal hypoglycemia, hypoxia, and acidosis $(29,30)$. The effects of this insult seemingly resolve days after birth in the human and 48 to $72 \mathrm{~h}$ after surgery in the rat, yet IUGR individuals are prone to develop insulin resistance and dyslipidemia as they reach maturity $(1,5,19,20)$. In the rat, these pathophysiologies are associated with altered skeletal muscle expression and function of key fatty acid oxidizing enzymes, as well as increased skeletal muscle triglycerides (9). Kelly et al. have proven that PGC-1 significantly contributes to the control of nuclear genes encoding mitochondrial fatty acids oxidation enzymes, and that expression of PGC-1 correlates directly with mRNA levels of these genes $(11,31)$. The finding of altered PGC-1 expression suggests a mechanism through which uteroplacental insufficiency affects mRNA levels of several skeletal muscle fatty acid oxidizing enzymes in the postnatal IUGR animal. This finding is novel because the association between an upstream transcriptional co-activator and subsequently affected gene expression has not been previously made in IUGR skeletal muscle.

PGC-1 stimulates skeletal muscle mitochondrial respiration and biogenesis through the induction of UCP-2 and NRF-1 expression respectively, as well as subsequent mTFA expression (10). The increased expression of NRF-1, mTFA, and COXIV in N0 skeletal muscle corroborate these findings, as well as the previous report of increased skeletal muscle mitochondrial gene expression in the N0 IUGR rat (8). In the adult rat, exercise stimulates PGC-1 expression, and Tunstall et al. found that exercise induced expression of PGC-1 was associated with increased expression of $\mathrm{mCPTI}$ and the $\beta$-oxidation enzyme $\beta$-hydroxyacyl-CoA dehydrogenase $(32,33)$. PGC-1 also restores glucose transporter 4 gene expression in cultured primary myotubes, which is intriguing within the context of the insulin resistance the IUGR rat develops and the decrease in PGC-1 soleus (Type I) muscle fiber expression observed in the present study (34). Primary myotubes exhibit a slow fiber phenotype (35).

This study finds no difference in rat hind limb fiber composition between the control and IUGR J21 rat pups. Little is otherwise known about skeletal muscle fiber type composition or differential expression in rat models that develop diabetes secondary to in utero deprivation through either uteroplacental insufficiency or maternal starvation. The WBN/Kob rat, which spontaneously develops diabetes, exhibits no significant change in fiber type composition that is not attributable to aging (36). In humans, the literature is ambiguous, though both Larsson et al. and Hickey et al. found no significant differences in muscle fiber type composition after the authors corrected the data for body mass index $(37,38)$.

EDL in the suckling rat contains a large proportion of fast fiber types (39). The increased expression of PGC-1 and mCPTI in EDL thereby explains the previously published findings of increased mCPTI expression and $\beta$-oxidation in juvenile hind limb, considering the hind limb predominance of fast fiber type found in this study (9). For soleus, the transition from a mixed fiber phenotype to a slow phenotype occurs over a period of 5 or more weeks (40). This delay may explain the increased lipid oxidation observed in IUGR infants and some of the discrepancies in the adult diabetic literature on whether fatty acid oxidation is increased or decreased in the NIDDM population, though the primary reason for the discrepancies is likely the large number of diabetic subtypes $(6,7,41-43)$. 
The human adult diabetic literature often uses vastus lateralis biopsies to characterize skeletal muscle metabolism in the diabetic population because of accessibility, and finds that enzyme activity for mitochondrial fatty acid oxidizing enzymes is decreased $(44,45)$. Vastus lateralis contains $30 \%$ to $40 \%$ type I muscle fibers (45). Considering the decreased soleus PGC-1 and mCPTI mRNA levels found in this study, it may be that the type I fibers of the diabetic vastus lateralis express less $\beta$-oxidation machinery and thereby oxidize less fatty acid versus nondiabetics, particularly in the adult where the slow fiber phenotype has fully evolved.

This is the first study to observe skeletal muscle gender specific differences in a rat model of IUGR and subsequent insulin resistance, though it is consistent with previous reports of more severely effected hepatic gene expression and function of fatty acid metabolizing genes in male IUGR rats $(19,46)$. Moreover, i.v. lipid emulsion induces insulin resistance in normal male adult rats to a significantly greater extent than it does in normal female adult rats $(47,48)$. Humans also metabolize fat in a gender specific manner $(48,49)$. Sumner et al. found that while obese diabetic African-Americans of both genders were resistant to insulin's glucoregulatory effects, only the men were resistant to insulin's antilipolytic effect (50). Because PGC-1 acts a transcriptional co-activator with estrogen and androgen receptors, the effects of PGC-1 gender specific expression, and subsequently the IUGR phenotype, potentially change as the IUGR individual progressively experiences sexual maturation, maturity, and senescence (51).

PGC-1 does not appear to effect CD36 mRNA levels in a manner similar to that of mCPT1 or UCP-2. Uteroplacental insufficiency increases CD36 expression in both EDL and soleus, and the findings are again gender specific, though they are more impressive in the female IUGR rats, which is different from PGC-1 and its down stream targets mCPTI and UCP2. The female IUGR rat does not exhibit hypertriglyceridemia to the same degree as the male, so it is intriguing that over expression of skeletal muscle CD36 decreases serum triglycerides in transgenic mice. CD36 mRNA expression is associated with increased skeletal muscle acyl-CoA synthase activity and fatty acid tissue storage (21). Increased levels of intramuscular triglycerides characterize both sexes of the IUGR rat, and have been closely linked to insulin resistance in human $(9,52$, 53).

Caution is necessary of course when attempting to apply data from a rat model to human pathophysiology. The fetal and juvenile rat is physiologically immature relative to the human, and the insult imposed on the fetal rat in this model of uteroplacental insufficiency is severe and specific. In contrast, the timing and impact of uteroplacental insufficiency experienced by humans range across a continuum.

In summary, uteroplacental insufficiency induces altered expression of PGC-1 and its downstream targets at both $\mathrm{N} 0$ and J21 life in hind limb skeletal muscle. RT-PCR demonstrates that the changes in mRNA levels are skeletal muscle group and gender specific. Skeletal muscle CD36 mRNA levels are also altered in the IUGR rat, though in a different pattern than PGC-1. We speculate that these changes in gene expression contribute to the alterations in skeletal muscle fat metabolism that occur in the IUGR rat and may contribute to the development of insulin resistance.

\section{REFERENCES}

1. Barker DJ, Hales CN, Fall CH, Osmond C, Phipps K, Clark PM 1993 Type 2 (non-insulin-dependent) diabetes mellitus, hypertension and hyperlipidaemia (syndrome X): relation to reduced fetal growth. Diabetologia 36:62-67

2. Phillips DI, Barker DJ, Hales CN, Hirst S, Osmond C 1994 Thinness at birth and insulin resistance in adult life. Diabetologia 37:150-154

3. Ogata ES, Bussey ME, LaBarbera A, Finley S 1985 Altered growth, hypoglycemia, hypoalaninemia, and ketonemia in the young rat: postnatal consequences of intrauterine growth retardation. Pediatr Res 19:32-37

4. Sadiq HF, Das UG, Tracy TF, Devaskar SU 1999 Intra-uterine growth restriction differentially regulates perinatal brain and skeletal muscle glucose transporters. Brain Res 823:96-103

5. Simmons RA, Templeton LJ, Gertz SJ 2001 Intrauterine growth retardation leads to the development of type 2 diabetes in the rat. Diabetes 50:2279-2286

6. Vaag A, Alford F, Henriksen FL, Christopher M, Beck-Nielsen H 1995 Multiple defects of both hepatic and peripheral intracellular glucose processing contribute to the hyperglycaemia of NIDDM. Diabetologia 38:326-336

7. Groop LC, Bonadonna RC, DelPrato S, Ratheiser K, Zyck K, Ferrannini E, DeFronzo RA 1989 Glucose and free fatty acid metabolism in non-insulin-dependent diabetes mellitus. Evidence for multiple sites of insulin resistance. J Clin Invest 84:205-213

8. Lane RH, Chandorkar AK, Flozak AS, Simmons RA 1998 Intrauterine growth retardation alters mitochondrial gene expression and function in fetal and juvenile rat skeletal muscle. Pediatr Res 43:563-570

9. Lane RH, Kelley DE, Ritov VH, Tsirka AE, Gruetzmacher EM 2001 Altered expression and function of mitochondrial beta-oxidation enzymes in juvenile intrauterine-growth-retarded rat skeletal muscle. Pediatr Res 50:83-90

10. Wu Z, Puigserver P, Andersson U, Zhang C, Adelmant G, Mootha V, Troy A, Cint S, Lowell B, Scarpulla RC, Spiegelman BM 1999 Mechanisms controlling mitochondrial biogenesis and respiration through the thermogenic coactivator PGC-1. Cell 98:115-124

11. Vega RB, Huss JM, Kelly DP 2000 The coactivator PGC-1 cooperates with peroxisome proliferator-activated receptor alpha in transcriptional control of nuclear genes encoding mitochondrial fatty acid oxidation enzymes. Mol Cell Biol 20:1868-1876

12. Lane RH, MacLennan NK, Hsu JL, Janke SM, Pham TD 2002 Increased hepatic peroxisome proliferator-activated receptor-gamma coactivator-1 gene expression in a rat model of intrauterine growth retardation and subsequent insulin resistance. Endocrinology 143:2486-2490

13. Ek J, Andersen G, Urhammer SA, Gaede PH, Drivsholm T, Borch-Johnsen K, Hansen $\mathrm{T}$, Pedersen O 2001 Mutation analysis of peroxisome proliferator-activated receptorgamma coactivator-1 (PGC-1) and relationships of identified amino acid polymorphisms to Type II diabetes mellitus. Diabetologia 44:2220-2226

14. Hara K, Tobe K, Okada T, Kadowaki H, Akanuma Y, Ito C, Kimura S, Kadowaki T 2002 A genetic variation in the PGC-1 gene and insulin resistance. Diabetologia 45:740-743

15. Bussey ME, Finley S, LaBarbera A, Ogata ES 1985 Hypoglycemia in the newborn growth-retarded rat: delayed phosphoenolpyruvate carboxykinase induction despite increased glucagon availability. Pediatr Res 19:363-367

16. Ogata ES, Swanson SL, Collins Jr JW, Finley SL 1990 Intrauterine growth retardation: altered hepatic energy and redox states in the fetal rat. Pediatr Res 27:56-63

17. Lane RH, Flozak AS, Ogata ES, Bell GI, Simmons RA 1996 Altered hepatic gene expression of enzymes involved in energy metabolism in the growth-retarded fetal rat. Pediatr Res 39:390-394

18. Lane RH, Crawford SE, Flozak AS, Simmons RA 1999 Localization and quantification of glucose transporters in liver of growth-retarded fetal and neonatal rats. Am J Physiol 276:E135-E142

19. Lane RH, Kelley DE, Gruetzmacher EM, Devaskar SU 2001 Uteroplacental insufficiency alters hepatic fatty acid-metabolizing enzymes in juvenile and adult rats. Am J Physiol Regul Integr Comp Physiol 280:R183-R190

20. Tsirka AE, Gruetzmacher EM, Kelley DE, Ritov VH, Devaskar SU, Lane RH 2001 Myocardial gene expression of glucose transporter 1 and glucose transporter 4 in response to uteroplacental insufficiency in the rat. J Endocrinol 169:373-380

21. Hegarty BD, Cooney GJ, Kraegen EW, Furler SM 2002 Increased efficiency of fatty acid uptake contributes to lipid accumulation in skeletal muscle of high fat-fed insulin-resistant rats. Diabetes 51:1477-1484

22. Kloesz JL, Serdikoff CM, Maclennan NK, Adibi SA, Lane RH 2001 Uteroplacental insufficiency alters liver and skeletal muscle branched-chain amino acid metabolism in intrauterine growth-restricted fetal rats. Pediatr Res 50:604-610

23. Wiedmer P, Klaus S, Ortmann S 2002 Energy metabolism of young rats after early postnatal overnutrition. Br J Nutr 88:301-306

24. Talmadge RJ, Roy RR 1993 Electrophoretic separation of rat skeletal muscle myosin heavy-chain isoforms. J Appl Physiol 75:2337-2340

25. LaFramboise WA, Daood MJ, Guthrie RD, Schiaffino S, Moretti P, Brozanski B, Ontell MP, Butler-Browne GS, Whalen RG, Ontell M 1991 Emergence of the mature myosin phenotype in the rat diaphragm muscle. Dev Biol 144:1-15

26. Chomczynski P, Sacchi N 1987 Single-step method of RNA isolation by acid guanidinium thiocyanate-phenol-chloroform extraction. Anal Biochem 162:156-159

27. Higuchi R, Fockler C, Dollinger G, Watson R 1993 Kinetic PCR analysis: real-time monitoring of DNA amplification reactions. Biotechnology (N Y) 11:1026-1030 
28. Menon RK, Shaufl A, Yu JH, Stephan DA, Friday RP 2001 Identification and characterization of a novel transcript of the murine growth hormone receptor gene exhibiting development- and tissue-specific expression. Mol Cell Endocrino $172: 135-146$

29. Ogata ES, Bussey ME, Finley S 1986 Altered gas exchange, limited glucose and branched chain amino acids, and hypoinsulinism retard fetal growth in the rat Metabolism 35:970-977

30. Economides DL, Nicolaides KH, Campbell S 1991 Metabolic and endocrine findings in appropriate and small for gestational age fetuses. J Perinat Med 19:97-105

31. Lehman JJ, Barger PM, Kovacs A, Saffitz JE, Medeiros DM, Kelly DP 2000 Peroxisome proliferator-activated receptor gamma coactivator-1 promotes cardiac mitochondrial biogenesis. J Clin Invest 106:847-856

32. Tunstall RJ, Mehan KA, Wadley GD, Collier GR, Bonen A, Hargreaves M, CameronSmith D 2002 Exercise training increases lipid metabolism gene expression in human skeletal muscle. Am J Physiol Endocrinol Metab 283:E66-E72

33. Goto M, Terada S, Kato M, Katoh M, Yokozeki T, Tabata I, Shimokawa T 2000 cDNA Cloning and mRNA analysis of PGC-1 in epitrochlearis muscle in swimmingexercised rats. Biochem Biophys Res Commun 274:350-354

34. Michael LF, Wu Z, Cheatham RB, Puigserver P, Adelmant G, Lehman JJ, Kelly DP, Spiegelman BM 2001 Restoration of insulin-sensitive glucose transporter (GLUT4) gene expression in muscle cells by the transcriptional coactivator PGC-1. Proc Nat Acad Sci U S A 98:3820-3825

35. Pin CL, Merrifield PA 2081997 Regionalized expression of myosin isoforms in heterotypic myotubes formed from embryonic and fetal rat myoblasts in vitro. Dev Dyn420-431

36. Ozaki K, Matsuura T, Narama I 2001 Histochemical and morphometrical analysis of skeletal muscle in spontaneous diabetic WBN/Kob rat. Acta Neuropathol (Berl) 102:264-270

37. Larsson H, Daugaard JR, Kiens B, Richter EA, Ahren B 1999 Muscle fiber characteristics in postmenopausal women with normal or impaired glucose tolerance. Diabetes Care 22:1330-1338

38. Hickey MS, Carey JO, Azevedo JL, Houmard JA, Pories WJ, Israel RG, Dohm GL 1995 Skeletal muscle fiber composition is related to adiposity and in vitro glucose transport rate in humans. Am J Physiol 268:E453-E457

39. Rubinstein NA, Kelly AM 1981 Development of muscle fiber specialization in the rat hindlimb. J Cell Biol 90:128-144

40. Kugelberg E 1976 Adaptive transformation of rat soleus motor units during growth J Neurol Sci 27:269-289
41. Chessex P, Reichman B, Verellen G, Putet G, Smith JM, Heim T, Swyer PR 1984 Metabolic consequences of intrauterine growth retardation in very low birthweight infants. Pediatr Res 18:709-713

42. Kelley DE, Simoneau JA 1994 Impaired free fatty acid utilization by skeletal muscle in non-insulin-dependent diabetes mellitus. J Clin Invest 94:2349-2356

43. Walker M, Berrish TS, Stewart MW, Humphriss DB, Barriocanal L, Alberti KG 1997 Metabolic heterogeneity in impaired glucose tolerance. Metabolism 46:914-917

44. Blaak EE, Wolffenbuttel BH, Saris WH, Pelsers MM, Wagenmakers AJ 2001 Weight reduction and the impaired plasma-derived free fatty acid oxidation in type 2 diabetic subjects. J Clin Endocrinol Metab 86:1638-1644

45. He J, Watkins S, Kelley DE 2001 Skeletal muscle lipid content and oxidative enzyme activity in relation to muscle fiber type in type 2 diabetes and obesity. Diabetes 50:817-823

46. Horton TJ, Gayles EC, Prach PA, Koppenhafer TA, Pagliassotti MJ 1997 Female rats do not develop sucrose-induced insulin resistance. Am J Physiol 272·R1571-R1576

47. Hevener A, Reichart D, Janez A, Olefsky J 2002 Female rats do not exhibit free fatty acid-induced insulin resistance. Diabetes 51:1907-1912

48. Binnert C, Koistinen HA, Martin G, Andreelli F, Ebeling P, Koivisto VA, Laville M, Auwerx J, Vidal H 2000 Fatty acid transport protein-1 mRNA expression in skeletal muscle and in adipose tissue in humans. Am J Physiol Endocrinol Metab 279:E1072E1079

49. Laws A, Hoen HM, Selby JV, Saad MF, Haffner SM, Howard BV 1997 Differences in insulin suppression of free fatty acid levels by gender and glucose tolerance status. Relation to plasma triglyceride and apolipoprotein B concentrations. Insulin Resistance Atherosclerosis Study (IRAS) Investigators. Arterioscler Thromb Vasc Biol 17:64-71

50. Sumner AE, Kushner H, Sherif KD, Tulenko TN, Falkner B, Marsh JB 1999 Sex differences in African-Americans regarding sensitivity to insulin's glucoregulatory and antilipolytic actions. Diabetes Care 22:71-77

51. Knutti D, Kaul A, Kralli A 2000 A tissue-specific coactivator of steroid receptors, identified in a functional genetic screen. Mol Cell Biol 20:2411-2422

52. Pan DA, Lillioja S, Kriketos AD, Milner MR, Baur LA, Bogardus C, Jenkins AB, Storlien LH 1997 Skeletal muscle triglyceride levels are inversely related to insulin action. Diabetes 46:983-988

53. Perseghin G, Scifo P, De Cobelli F, Pagliato E, Battezzati A, Arcelloni C, Vanzulli A, Testolin G, Pozza G, Del Maschio A, Luzi L 1999 Intramyocellular triglyceride content is a determinant of in vivo insulin resistance in humans: a $1 \mathrm{H}-13 \mathrm{C}$ nuclear magnetic resonance spectroscopy assessment in offspring of type 2 diabetic parents. Diabetes 48:1600-1606 